\title{
Effectiveness of Competency Based Online Learning: Improving Listening and Speaking in Contextual Oral Language Skills Course
}

\author{
$1^{\text {st }}$ Yeni Erlita ${ }^{1}, 2^{\text {nd }}$ Ade Aini Nuran ${ }^{2}, 3^{\text {rd }}$ Fadlin Simangunsong ${ }^{3}, 4^{\text {th }}$ Selvy Noer Haiyu ${ }^{4}$ \\ \{yenierlitafbs@unimed.ac.id ${ }^{1}$, adeaini@unimed.ac.id ${ }^{2}$, siman1709@gmail.com $^{3}$ \} \\ English Education Study Program, English and Literature Department, Universitas Negeri Medan, \\ Indonesia ${ }^{1,2,3,4}$
}

\begin{abstract}
This study was to determine the effectiveness of online learning implementation in improving students' listening and speaking skills in Contextual Oral Language Skills course. It was research and development (R\&D) research. The subject of this study were the students of semester 3 from two different classes. The effectiveness can be seen by treatments done and by distributing questionnaire to know the students' perspective about the effectiveness of Google Classroom and Zoom, and measured students learning outcomes. The result found that there were $96.8 \%$ students who agreed learning became more flexible with Google Classroom, and $73.8 \%$ students be more active in learning process using Zoom. Furthermore, students learning outcomes were higher than the minimum standard of mastery learning (KKM) which totally for listening was 85.42, and speaking was 83.74. The conclusion was online learning has an effectiveness to the students' improvement in speaking and listening skills through Google Classroom and Zoom.
\end{abstract}

Keywords: Effectiveness, Online Learning, Google Classroom, Zoom, Contextual Oral Language Skills.

\section{Introduction}

The Covid-19 pandemic has not only affected the economic and social sectors, but also the education sector, which now inevitably has to start adapting to this era. So, the learning activities which originally carried out face-to-face turned into non-face-to-face learning. This program is known as online learning or e-learning. Online learning is the use of an internet network in the learning process [1]. So, online learning is an effort to teach students which are done without face-to-face through the available internet. In face-to-face learning process in listening and speaking class, lecturers can use laptops, LCD, or audio-speaker in the classroom or language laboratory. One of the challenges faced in learning during the Covid-19 pandemic is the lack or limited opportunities for lecturers and students to interact directly and freely during online learning which caused in disruption of the learning process. A learning situation in this pandemic, lecturers are required to be more active in understanding how to communicate to students with clearly different languages and tools [2].

The internet has been integrated as a tool to complement language learning activities [3]. Several advantages of using online media on the internet, including providing opportunities for students and lecturers to pay attention to language forms, as providing input modification, 
providing various learning resources for collaborative projects, as a multimodal practice tool such as visuals, auditory and written, and as a fun medium [4]. In this online learning, the material is presented by online, online chat, and online discussion. Online media (Virtual Meeting) used such as Zoom Meeting, Youtube, WhatsApp, Google Classroom, and Quizzes. The material is given in the form of powerpoints, short videos, and reading materials. The use of learning media and online learning methods must be used by lecturers maximally. It is to support the implementation of online learning during the pandemic in an undetermined period. Contextual Oral Language Skills subject is carried out in online. One of the phenomena found was that some students and lecturers got problems with erratic network connections, so that one of the lecturers' problem is the lack of student understanding of the learning material, which could affect listening and speaking skills. Therefore, some lecturers use interactive media that can be accessed and learned freely by students, such as using YouTube, Zoom or Google Classroom media.

The teaching and learning process must be always an increasing in effectiveness to achieve the goals. Each student can access freely based to the material and learning objectives that have been determined by the lecturer. The freedom and relative time of students in learning is certainly expected to make learning run effectively towards improving students' listening and speaking skills. However, in the implementation of online learning, it is necessary to evaluate to obtain clear data-based improvement steps. This is what underlies the author to find out the description of the effectiveness of online learning on improving students' listening and speaking skills in this Contextual Oral Language Skills course.

The purpose of this study is to determine the effectiveness of the implementation of online learning on improving students' listening and speaking skills in the Contextual Oral Language Skills course, to provide information about the development of online teaching learning process for listening and speaking competencies through e-Learning.

\section{Method}

This research is a research and development (R\&D) research. Research and development (R\&D) is an effort or activity to develop an effective product to used by schools, and not to test the theory. Meanwhile, (R\&D) research as a process used to develop and validate educational products [5]. In this study, the Research and Development (R\&D) method will be used to develop or make a product. The location of the research was carried out at the Languages and Arts Faculty in the Contextual Oral Language Skills course at the English Education Study Program, Unimed, at Willem Iskandar Pasar V, Medan. The population and sample in this study were the 3rd-semester students in the Contextual Oral Language Skills course, Regular Education Class E and F.

The research process begins with analyzing the needs of digital online learning media for the teaching of Contextual Oral Language Skills. Then conduct a limited trial on selected media which has been validated by 2 expert lecturers in the Department of English Language and Literature, Languages and Arts Faculty, Unimed. Lastly, the data collection process was carried out by distributing online questionnaires to the students of class $\mathrm{E}$ and $\mathrm{F}$ via google form to determine the quality and effectiveness of the e-learning media used. As well as the use of the rubric for assessment of learning outcomes in the Contextual Oral Language Skills course to measure the effectiveness of the e-learning media. There were 3 indicators which 
assessed as effectiveness of learning, including; 1) online learning planning, 2) the use of online media, 3) and student learning outcomes.

\section{Results and Discussion}

Competency-based learning can be defined as: "learning program in which the learning outcomes or competencies that are expected to be achieved by students, storage systems and indicators of achievement of learning outcomes are formulated in writing since planning begins. And this is related to the effectiveness of learning which according to Afifatu (in Fathurrachman et al., 2019: 2), effectiveness is a measure of the success of an interaction process between students and students, and teachers in educational situations to achieve learning goals ${ }^{1}$. Then, online learning is a form of distance education in which the material is delivered via the internet (on a network) [6]. Based on the statement above, it can be concluded that to achieve effective online learning, some planning must be carried out by the teacher. Based on this explanation, there were 3 points that explained the effectiveness of online learning in improving students' listening and speaking skills in Contextual Oral Language Skills courses based on research results, including;

\subsection{Online Learning Preparation}

Online Learning. An e-learning process is learning by utilizing internet technology to improve the learning environment with rich content with a broad scope. The process of implementing online learning must continue to be carried out according to procedures that cover the needs of students and teachers and are based on a predetermined syllabus and curriculum. Based on the achievement of learning effectiveness, also the effective learning cannot be separated from the role of effective teachers, effective learning conditions, student involvement, and a supportive learning environment. In this case, lecturers have an important role in preparing this online learning process.

Based on the learning system that has been applied previously in the English language and literature department, the online learning model has been applied several times before the pandemic, such as the blended learning and flipped learning models, which students and lecturers were actively involved in the online and face-to-face learning process. Applications or platforms that were often used by lecturers are Schoology, WhatsApp, and SIPDA (Online Learning System at Languages and Arts Faculty). So it can be understood that the online learning system already has a good level of preparation. Lecturers already understood the process of preparing for online learning, from the provision of the media used, learning materials, form of assignments, and learning strategies that will be used in online learning. Likewise, students who have understood the overall learning that will be carried out. This will have an impact on the performance of lecturers and students, who are much more effective of time because it is not too difficult to carry out online learning regularly during the pandemic, and it does not take a long time to adapt to online learning process. In addition, lecturers maximize their role as facilitators to develop learning methods so that learning runs effectively, because the intensity of online learning is higher than before.

\footnotetext{
${ }^{1}$ http://journal.unj.ac.id/unj/index.php/ijlecr
} 
The increase in the intensity of online learning, it required a virtual communication supported tool between lecturers and students with a higher level of functionality and effectiveness. Therefore, planning is needed to support learning media. The planning is done by analyzing the media needs first, which the media can support the learning process and all aspects of learning in the Contextual Oral Language Skills course. The effectiveness of learning can be achieved, one of which is by using learning media in the learning process that is in accordance with the situation and conditions, both from the content of the material or the state of the student environment [7]. Contextual Oral Language Skills is a course that involved listening and speaking skills, so one of the media needs was being able to be used in listening and speaking activities by lecturers and students, interactive and a good feedback system.

\subsection{The Using of Google Classroom and Zoom}

Online learning media is a type of teaching and learning that allowed the delivery of teaching materials to students using Internet media. The use of media was basically intended to help learning activities be more effective in achieving goals and efficient in terms of energy, time and cost [8]. Technology is experiencing significant changes that can help learning activities, with the Google Meet application, Google Classroom, Zoom Meeting and so on. So based on the usability and needs, there were 2 learning media used in Contextual Oral Language Skills courses, such as Google Classroom and Zoom Meeting or Video Conference.

Google Classroom. Google classroom is designed to help educators create and submit paperless assignments. As well as streamlining and facilitating interaction between lecturers and students in cyberspace during the online learning period. This application is very helpful in the learning process by lecturers and students in facilitating the learning process. Optimizing Google classroom features has a significant impact on learning in the digital era, including: (1) learning by utilizing technology is carried out online, (2) flexible because it is not limited by space and time, (3) students are independently directly involved in the learning process. learning that utilizes the internet, (4) learning materials provided by educators are easily accessible to students, (5) improve data literacy and technological literacy skills. In addition, the creation of Google classroom can also be done easily by educators to make online learning more effective and efficient [9]. Below are student responses to the effectiveness of using Google Classroom in learning Contextual Oral Language Skills.

Based on the data in Table 1, it can be seen that from a total of 65 student. respondents, more than half of the students stated that they strongly agree and agree with the effectiveness of using Google Classroom. Although there were some who disagreed on several aspects, for example, there was 1 student who disagreed that Google Classroom was easy to use and could make learning Contextual Oral Language Skills material easier. Plus 5 students who disagreed that Google Classroom can increase student productivity. 
Table 1. Students' responds of google classroom effectiveness.

\begin{tabular}{|c|c|c|c|c|c|}
\hline \multirow{2}{*}{ No } & \multirow{2}{*}{ Question } & \multicolumn{4}{|c|}{ Respond } \\
\hline & & SA & A & D & SDA \\
\hline 1 & $\begin{array}{l}\text { Using Google Classroom is easy to access in COLS } \\
\text { learning }\end{array}$ & 38 & 26 & 1 & 0 \\
\hline 2 & $\begin{array}{l}\text { Material information presented through Google } \\
\text { Classroom can help to learn and understand COLS } \\
\text { material }\end{array}$ & 29 & 35 & 1 & 0 \\
\hline 3 & $\begin{array}{l}\text { Using Google Classroom, COLS course announcements, } \\
\text { materials, and assignments become more flexible }\end{array}$ & 43 & 20 & 2 & 0 \\
\hline 4 & $\begin{array}{l}\text { Using Google Classroom can make it easier for me to } \\
\text { complete COLS course assignments }\end{array}$ & 36 & 29 & 0 & 0 \\
\hline 5 & $\begin{array}{l}\text { Using Google Classroom can increase my study } \\
\text { productivity }\end{array}$ & 21 & 38 & 5 & 1 \\
\hline
\end{tabular}

For a more detailed explanation, it will be explained based on the percentage data in the diagram below.

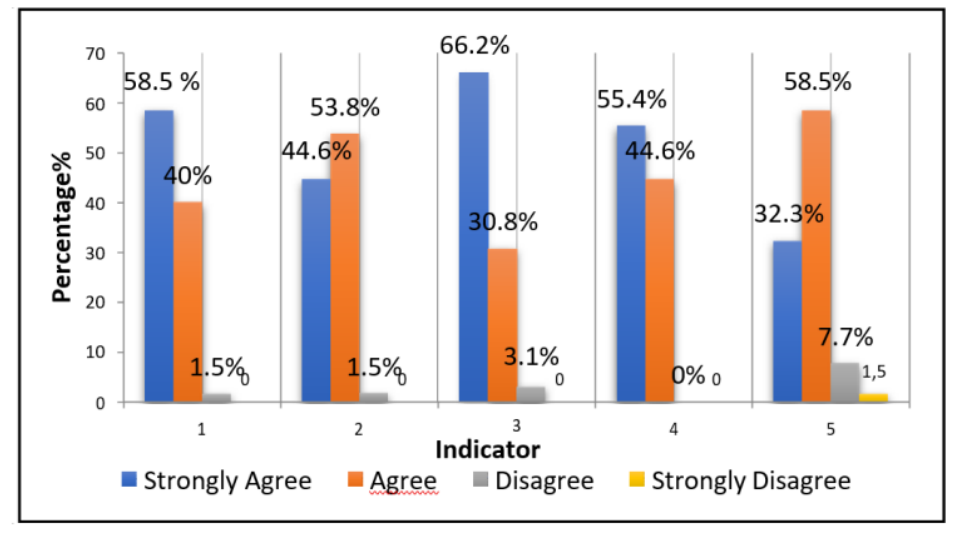

Fig.1. Percentage of students' responds of google classroom effectiveness.

In point 1 seen in the diagram above, $58 \%$ of students strongly agree and $40 \%$ agree that Google Classroom is easy to use. And there were only $1.5 \%$ of students who did not agree with the statement. This was explained that Google Classroom was stated as a medium that is easily accessible by students when carrying out learning. As known, to access Google Classroom, lecturers and students only need to have a google mail account to be able to connect with each other by creating a learning room that is given a code.

In point 2, explained the delivery of material with Google Classroom made it easier for students to understand the Contextual Oral Language Skills material, 44\% stated strongly agree and $53.8 \%$ agreed. While disagree $1.5 \%$. In point 3 about the form of assignments, and the material is more flexible using Google Classroom. Regarding this matter, $66.2 \%$ strongly agree, and $30.8 \%$ agree. And there were $3.1 \%$ who disagree. Points 2 and 3 were points that explain the effectiveness of delivering material and the assignment of Contextual Oral Language Skills, so it can be understood from these data that Google Classroom has a good 
level of effectiveness in terms of delivering material. As in a study about the effectiveness of Google Classroom learning which aspects of the delivery or delivery method of Google Classroom learning showed the category was quite effective with a tendency rate of $75 \%$.

This was because the lecturer conveys the material for each lecture by sharing the material in the material menu on Google Classroom and students can download it easily, after that it is discussed in the Forum menu. Google classroom can display material and assignments in the form of questions, besides that it can send material in the form of power points and also includes a link that is directly connected to youtube. Google Classroom was more often used for Listening assignments in COLS courses because lecturers simply share videos from YouTube by attaching the link. With the Google classroom, it was expected that its use will become more effective along with the development of technology and learning methods used [9].

Point 4 explained that completing assignments with Google Classroom was easier, 55.4\% strongly agree, and $44.6 \%$ agree. Point 5 explains the impact of Google Classroom on student productivity, $32.3 \%$ strongly agree, and 58.5\% agree, and 1.5\% disagree. Points 4 and 5 explained the effectiveness of Google Classroom on student learning. Based on these data, Google Classroom has a good impact on student learning productivity, one of which was that students can collect assignments more easily, can be done directly in Google classroom without the need to write notes or answers in notebooks and print assignments, thus saving costs.

Based on the explanation of these data, it can be concluded that Google Classroom as a learning media shows that learning is very effective, because it gets a lot of positive responses from students, and other users. The feasibility of Google Classroom as a learning medium showed a very good average validation result, so it can be said that it is feasible as a learning medium [10].

Zoom. Zoom Meeting Online Learning was learning which delivered electronically that can support communication needs anywhere and anytime with many people without having to physically meet directly between students and teachers at the same time [11]. The use of this zoom media will greatly help teachers and students in the learning process because they can interact and communicate face-to-face even in different places. And make it easier for lecturers to control students. This is in accordance with the opinion expressed earning to use Zoom Meetings to overcome the limitations between educators and students, especially in terms of space and time, which educators and students do not have to be in one dimension of space and time, learning can run by ignoring these two things [12].

Unlike the case with Google Classroom, which almost all students agree on its effectiveness. Meanwhile, Zoom can be seen in Table 2, which the number of those who agree and disagree is almost the same, although the number of those who agree is still larger.

Table 2. Students' responds of Zoom Meeting Effectiveness.

\begin{tabular}{llllll}
\hline \multirow{2}{*}{ No } & Question & \multicolumn{2}{l}{ Respond } & \\
\cline { 3 - 5 } & SA & A & D & SD \\
\hline \multirow{2}{*}{1} & $\begin{array}{l}\text { By using Zoom Meeting, I can focus on listening and seeing } \\
\text { the lecturer who is presenting the material on one screen }\end{array}$ & 21 & 34 & 9 & 1
\end{tabular}

\footnotetext{
${ }^{2}$ The effectiveness of Google Classroom learning which aspects of the delivery or delivery method of Google Classroom learning (Sholeh, 2021).
} 
2 It is very easy for me to remember the COLS material presented by the teacher if I go through Zoom Meetings

3 By using Zoom Meeting media I become more active in learning activities and more effective

4 The use of Zoom Meeting media makes it easier for me to understand the material presented.

5 I enjoy learning to use Zoom Meeting because it makes it easier for me to follow the learning process.

$\begin{array}{llll}8 & 47 & 9 & 1 \\ 9 & 39 & 16 & 1 \\ 10 & 42 & 12 & 1 \\ 12 & 40 & 13 & 0\end{array}$

For a more detailed explanation, see the percentage data in the diagram below.

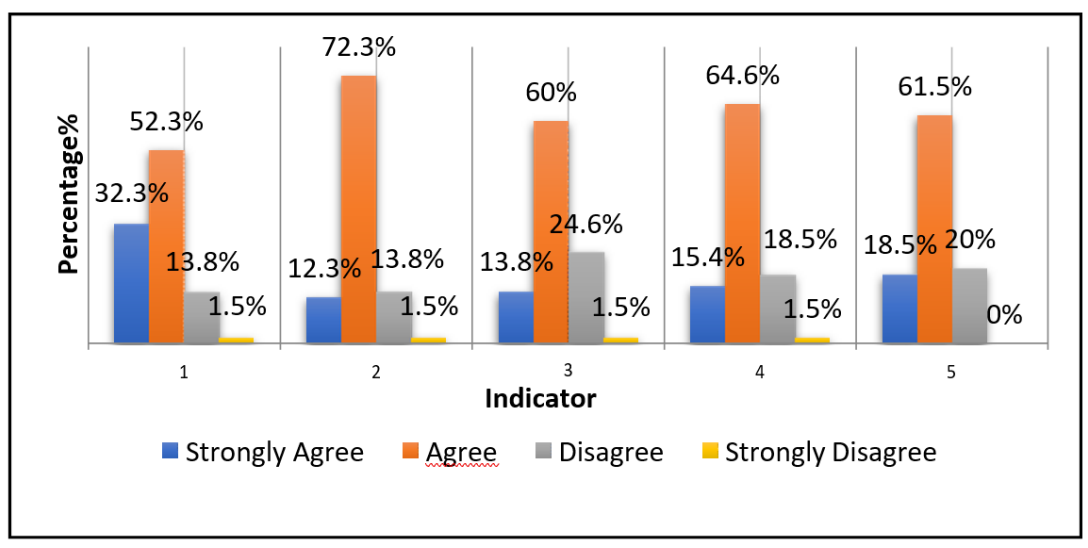

Fig.2. Percentage of students' responds of zoom meeting effectiveness.

In point 1 as seen in the diagram above, $32.3 \%$ of students strongly agree and $52.3 \%$ agree that the presence of Zoom made students more focused on listening to lecturers' explanations. And $18.8 \%$ did not agree, and there were $1.5 \%$ students who strongly disagreed with the statement. Point 2 explains that Zoom makes it easier for students to remember COLS material, it can be seen that $44 \%$ strongly agree and $53.8 \%$ agree. While disagree $1.5 \%$. Points 1 and 2 are interrelated about Zoom making it easier for students to understand the COLS learning material delivered by the lecturer. This was also seen in point 4 explaining that it made it easier for students to understand the material presented, $55.4 \%$ strongly agree, and $44.6 \%$ agree. So, it can be understood that Zoom has a good level of effectiveness.

In point 3 about the impact of Zoom on student activity in COLS learning. Regarding this matter, $66.2 \%$ strongly agree, and $30.8 \%$ agree. And there are $3.1 \%$ who disagree. From these data, it is concluded that the use of Zoom has a good impact on the level of student activity in the learning process. As learning through video conference, besides being able to display learning material on display and can be seen by all participants, so that participants not only hear explanations but can also observe the material provided, but also optimize the direct interaction between students, learning companions and educators.

Point 5 explained that it made it easier for students to follow the learning process, $32.3 \%$ strongly agree, and $58.5 \%$ agree. And $1.5 \%$ disagree. It can be seen from the learning process, students are able to listen to the material clearly without any obstacles. Learning can also be carried out even though in different places, because learning using Zoom Meeting was not limited by distance and time. Effective was meant in the use of this application that was 
effective in terms of time and place. The effectiveness of the facilities, with the Zoom Meeting application, students or lecturers can use the conversation transcript and video call features, students can record conversations and video calls without having to activate or operate additional applications, simply change or adjust the settings in the Zoom Meeting application and can be viewed again on their respective devices or accounts. With video conferencing, it will help the learning process carried out, because educators will be directly involved with students [13].

Learning media in online education was used as a tool to improve the efficiency and effectiveness of education [14]. Based on the explanation of these data performance with the Zoom application as a learning medium, it can be said that $70 \%$ said the performance of video conferencing with the Zoom Cloud ID application as a learning medium had very good criteria which had a good level of efficiency.

\subsection{Learning Outcomes}

Effective learning was learning which in the process must involved students or students actively, so that learning objectives are achieved properly. Effectiveness was a measure of the success of an interaction process between students and students, and teachers in educational situations to achieve learning goals. Below are student learning outcomes using Google Classroom and Zoom.

Listening. The assessment of listening task in the Contextual Oral Language Skills course was divided into 6 tasks, which were task 1, task 2, critical journal review (CJR), task 3, critical book report (CBR), task 4, task 5, and task 6 . Students' understanding to the material can be seen through their learning outcomes. If the learning outcomes were good, it indicated that the students have understood the material presented by the lecturer. In terms of understanding the material, students felt that they have had enough with the results of assignments whose average score was above 80 . With the achievement of results above the average, the learning objectives are achieved well, which indicated that learning was running effectively.

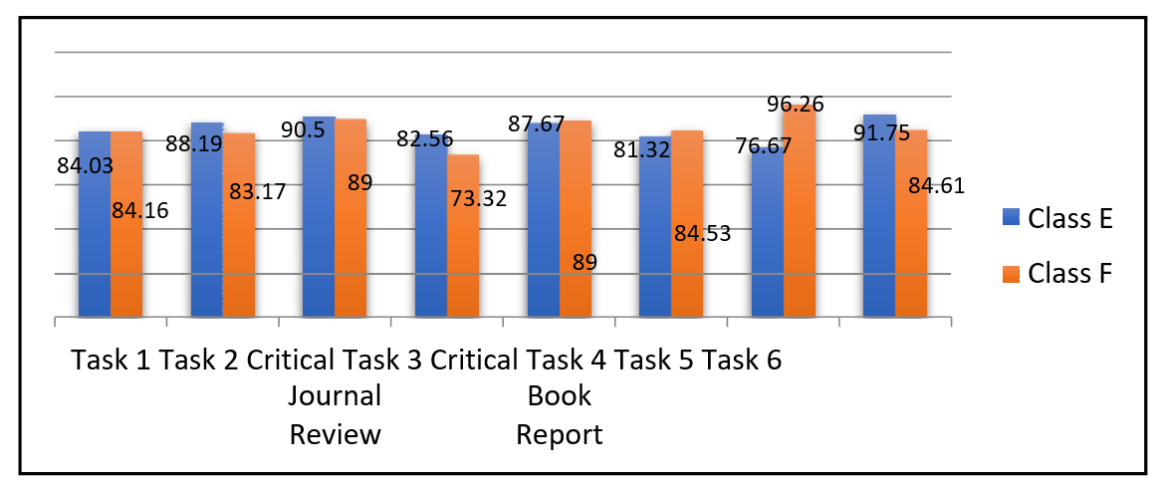

Fig. 3. Average score of students' learning outcomes for listening skill.

Based on the data in the diagram above, all assignments in class $\mathrm{E}$ and $\mathrm{F}$ were already above the average score. For class E, the highest average score was on task 6 which was 91.75 , while the lowest was 76.67 on task 5 . For class $\mathrm{F}$, the highest average score is on task 5 
which was 96.26 , and the lowest was 73.32 on task 3 . From these data it was concluded that each class has 1 task that was below the average, which task 5 was for class E, and task 3 was for class F. So it can be concluded that student learning outcomes for learning skills in Contextual Oral Language Skills were increasing when using Google Classroom and Zoom, although not too significantly.

Speaking. Assignment assessment on speaking skills consists of 3 forms of assessment, which are Question and Answer, Pronunciation, and Intonation.

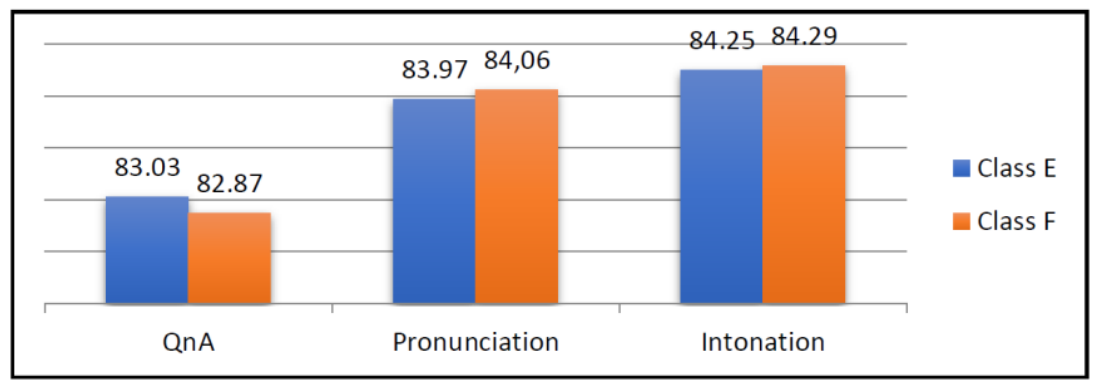

Fig. 4. Average score of students' learning outcomes for speaking skill.

Based on the data above, all aspects of the assessment of class E, and F were already above the average score. For the Question and Answer assessment, the average score of class E was much higher than class F, which was 83.03 for class E, and 82.87 for class F. For pronunciation assessment, the average score of class $\mathrm{F}$ was much higher than class $\mathrm{E}$, and the score was the average of class $\mathrm{F}$ is 84.06 , and the average of class $\mathrm{E}$ is 83.97. As for the intonation assessment, the average scores for class E and F only differ slightly, which 84.25 for class E and 84.29 for class F. From these data it can also be seen that the intonation assessment was the highest average score, while the lowest one on the Question and Answer assessment.

Therefore, it can be concluded that students' learning outcomes for speaking skills in Contextual Oral Language Skills also increased as well as listening skills. Even in speaking skills, there were no scores below the average score. From the two data between speaking and listening skills in Contextual Oral Language Skills, it can be concluded that the use of Google Classroom and Zoom media in the learning process has been effective in improving students' speaking and listening skills. This states that learning is effective even though it is done online.

\section{Conclusion}

Online learning is an effort to teach students which are done without face-to-face through the available internet. Lecturers are required to be more active in understanding how to communicate to students by using technology with clearly different languages and tools. To support the implementation of online learning, the using of learning media and online learning methods must be used by lecturers maximally. The teaching and learning process must be 
always an increasing in effectiveness to achieve the goals. Each student can access freely based to the material and learning objectives that have been determined by the lecturer. Google Classroom and Zoom are two alternative media that have good effectiveness in terms of ease of access, good efficiency in the learning process, and good impact on student learning outcomes. Students' listening and speaking skills in using Google Classroom and Zoom have increased, which all the average scores are above the average, which is above 80 . It is concluded that online learning using Google Classroom and Zoom has a good level of effectiveness on listening skills. and speaking in the Contextual Oral Language Skills course.

\section{References}

[1] Isman M. Pembelajaran Moda Dalam Jaringan (Moda Daring). The Progressive and Fun education Seminar. 2016:586-588.

[2] Huang RH, Liu DJ, Tlili A, Yang J, Wang H. Handbook on Facilitating Flexible Learning during Educational Disruption: The Chinese Experience in Maintaining Undisrupted Learning in COVID19 Outbreak. Beijing: Smart Learning Institute of Beijing Normal University; 2020.

[3] Martins M. How to Effectively Integrate Technology in the Foreign Language Classroom for Learning and Collaboration. Procedia - Social and Behavioral Sciences. Elsevier; 2015. p. 77-84.

[4] Brown HD. Teaching by principles: An interactive approach to language pedagogy. New York: Personal Education; 2007.

[5] Borg WR, Gall MD. Educational research an introduction. $4^{\text {th }}$ Edition. New York: Longman Inc; 1983.

[6] Bates T. Online Learning in the (K-12) School System. [Presentation] Commonwealth of Learning. December 2020.

[7] Wibawanto W. Desain dan Program Multimedia Pembelajaran Interaktif. Jember: Cerdas Ulet Kreatif; 2017.

[8] Falahudin I. Pemanfaatan Media dalam Pembelajaran. J Lingkar Widyaiswara. 2014; 1(4):104-117.

[9] Silahuddin. Penerapan E- Learning dalam Inovasi Pendidikan. CIRCUIT. J Ilmiah Pendidikan Tek Elektro. 2015; 1(1):48-59.

[10] Hikmatiar A, Sulisworo D, Wahyuni M. Pemanfaatan Learning Management System Berbasis Google Classroom dalam Pembelajaran. J Pendidikan Fisika. 2020; 8(1):1-9.

[11] Liu AN. Pengaruh Pembelajaran Online Berbasis Zoom Cloud Meeting Terhadap Hasil Belajar Mahasiswa Fisika Universitas Flores. J JPFK. 2020; 6(1):34-38.

[12] Ismawati D, Prasetyo I. Efektivitas Pembelajaran Menggunakan Video Zoom Cloud Meeting di Era Pandemi Covid-19. J Pendidikan Anak Usia Dini. 2021; 5(1):665-675.

[13] Sandiwarno. Perancangan Model E-Learning Berbasis Collaborative Video Conference Learning guna Mendapatkan Hasil Pembelajaran yang Efektif dan Efisien. J Ilmiah FIFO. 2016; 8(2):191200.

[14] Supardi SU, Leonard, Suhendri H, Rismurdiyati. Pengaruh Media Pembelajaran dan Minat Belajar Terhadap Hasil Belajar Fisika Formatif. J Ilmiah Pendidikan MIPA. 2015; 2(1):71-81. 